\title{
PENGARUH VARIASI KONSENTRASI HIDROLISIS ASAM SULFAT TERHADAP SIFAT MEKANIK PLASTIK SELULOSA TEREGENERASI DARI KAPAS LIMBAH TEKSTIL DENGAN PELARUT NaOH/UREA
}

\author{
Raden Reza Rizkiansyah, Mardiyati dan Steven \\ Program Studi Teknik Material, Fakultas Teknik Mesin dan Dirgantara - ITB \\ Jl. Ganesha 10, Bandung, 40132 \\ E-mail: raden.reza.rizkiansyah@gmail.com
}

\begin{abstract}
ABSTRAK
PENGARUH VARIASI KONSENTRASI HIDROLISIS ASAM SULFAT TERHADAP SIFAT MEKANIK PLASTIK SELULOSA TEREGENERASI DARI KAPAS LIMBAH DENGAN PELARUT NaOH/UREA. Selulosa merupakan polimer alami dengan ketersediaan yang paling melimpah yang berpotensi untuk direkayasa menjadi suatu plastik biodegradable. Selulosa teregenerasi merupakan suatu material yang dibentuk dengan cara melarutkan selulosa dalam palarut tertentu dan dicetak. Dalam penelitian ini, kapas limbah dari industri tekstil digunakan sebagai sumber selulosa. Kapas pada dasarnya memiliki kandungan selulosa yang sangat tinggi, yakni sekitar $86 \%$ hingga $98 \%$. Selulosa diekstrak dari kapas limbah dengan hidrolisis asam sulfat dengan konsentrasi divariasikan pada $0,5 \mathrm{M} ; 1 \mathrm{M} ; 1,5 \mathrm{M}$ dan $0,5 \mathrm{M}$ dengan suhu $100{ }^{\circ} \mathrm{C}$ selama 2 jam. Selulosa teregenerasi dibuat dengan melarutkan selulosa pada larutan $\mathrm{NaOH} 7 \% /$ Urea $12 \%$ dan dibentuk dengan metode solution casting. Berat molekul selulosa diukur dengan metode berat molekul rerata viskositas dengan viskometer Ubbelohde. Karakterisasi yang dilakukan menunjukkan peningkatan konsentrasi asam sulfat yang digunakan menyebabkan penurunan berat molekul selulosa yang terekstraksi. Berat molekul selulosa yang digunakan akan turut berpengaruh terhadap sifat mekanik dari plastik yang dihasilkan. Sifat optimum selulosa teregenerasi yang dihasilkan diperoleh dari selulosa dengan berat molekul $2,73 \times 10^{4} \mathrm{~g} / \mathrm{mol}$ dari hasil hidrolisis $0,5 \mathrm{M}$, yang dimana memiliki kekuatan tarik, persen elongasi dan modulus masing-masing sebesar 49,24 MPa; 0,92\%; dan 11,39 GPa dengan densitas sebesar 1,53 g/ $\mathrm{cm}^{3}$.
\end{abstract}

Kata kunci: Berat molekul, Hidrolisis, Kapas, Selulosa teregenerasi, Sifat mekanik

\begin{abstract}
INFLUENCE OF ACID CONCENTRATION TO MECHANICAL PROPERTIES OF REGENERATED CELLULOSE PLASTIC FROM TEXTILE INDUSTRY COTTON WASTE. Cellulose is most abundant naturally occurred polymer which has potential to be engineered into biodegradable plastic. Regenerated cellulose is a class of material formed by dissolving cellulose into a certain solvent and casted into desired shape. In this research, waste cotton from textile industry are used as source of cellulose. Cotton basically have high content of cellulose, which around 86-98 \%. Cellulose extracted from waste cottonusing sulfuric acid hydrolysiswith the concentration varied in $0.5 ; 1 ; 1.5$ and $2 \mathrm{M}$ in $100{ }^{\circ} \mathrm{C}$ for 2 hours. Regenerated cellulose is prepared by dissolving cellulose with $\mathrm{NaOH} 7 \mathrm{wt} \% /$ Urea $12 \mathrm{wt} \%$ and formedby solution casting method. Molecular weight of cellulose was investigated by viscosity average molecular weight method using Ubbelohde viscometer. Characterization conducted in this research suggested that the increase of sulfuric acid concentration used in the extraction resulted with the decrease of the molecular weight of the extracted cellulose. The optimal properties of the regenerated cellulose were obtained from cellulose with molecular weight $2.73 \times 10^{4} \mathrm{~g} / \mathrm{mol}$ extracted with sulfuric acid hydrolysis in $0,5 \mathrm{M}$, which resulted in regenerated cellulose with tensile strength, percent of elongation, and modulus $49.24 \mathrm{MPa}$; $0.92 \%$; and $11.39 \mathrm{GPa}$ resepectively and density $1.53 \mathrm{~g} / \mathrm{cm}^{3}$.
\end{abstract}

Keywords: Cotton, Hydrolysis, Mechanical properties, Molecular weight, Regenerated cellulose 


\section{PENDAHULUAN}

Permasalahan penumpukan sampah plastik yang tidak dapat terbiodegradasi secara alami merupakan salah satu hal yang saat ini menjadi isu utama dalam hal pencemaran lingkungan. Salah satu alternatif yang saat ini dilakukan untuk mengatasi masalah tersebut adalah dengan mengembangkan jenis plastik yang dapat terdegradasi secara alami di alam yang umumnya dibuat dari polimer hayati. Selulosa merupakan salah satu jenis polimer yang terbentuk secara alami di alam dengan ketersediaan paling melimpah di bumi yang berasal dari tumbuhan, dihasilkan 100 miliar ton selulosa setiap tahun [1]. Ketersediaan yang melimpah dan sifatnya dapat yang diperbaharui menjadikan sebagai bahan alam yang memiliki potensi untuk dimanfaatkan sebagai bahan baku pembuatan plastik, khususnya untuk plastik ramah lingkungan yang dapat terbiodegradasi secara alami.

Selulosa teregenerasi merupakan salah satu hasil pengolahan selulosa yang diperoleh dengan cara melarutkan selulosa, dicetak dan diregenerasi kembali menjadi suatu produk plastik. Selulosa teregenerasi memiliki karakteristik utama yakni tersusun atas molekul selulosa yang sama dengan kondisi native atau tidak termodifikasi. Proses pembuatan selulosa teregenerasi yang telah tersedia dalam skala industri hingga saat ini adalah melalui proses viscose, yang menggunakan campuran karbon disulfide dan $\mathrm{NaOH}$ sebagai pelarutnya [2]. Proses viscose pada dasarnya kurang disukai karena menghasilkan limbah beracun yang sulit untuk diolah [2], sehingga berpotensi mencemari lingkungan.

Permasalahan terhadap pelarut viscose tersebut kemudian mendorong untuk dikembangkannya pelarut selulosa alternatif. Penggunaan larutan $\mathrm{NaOH} / \mathrm{Urea}$ dalam kondisi suhu dibawah $0{ }^{\circ} \mathrm{C}$ merupakan salah satu alternatif terbaru metode pelarutan selulosa. Metode pelarutan ini dikembangkan oleh Zhang pada tahun 2000. Penggunaan larutan $\mathrm{NaOH}$ dan Urea tersebut diklaim lebih tidak beracun dan lebih murah dibandingkan dengan proses viscose [3], sehingga menjadikan proses tersebut banyak diteliti untuk dikembangkan lebih lanjut.

Dalam penelitian ini akan dikaji pemanfaatan kapas limbah dari industri pembuatan benang katun sebagai sumber selulosa alternatif yang kemudian diproses lebih lanjut menjadi plastik selulosa teregenerasi dengan pelarut $\mathrm{NaOH} / \mathrm{Urea}$. Pemilihan kapas limbah sebagai sumber bahan baku selulosa dalam penelitian ini dilatarbelakangi oleh kandungan selulosa dari kapas berkisar $88 \%$ hingga $96 \%$ [4] dan potensi dari limbah kapas tekstil yang besar, mengingat Indonesia merupakan salah satu negara produsen benang katun terbesar di dunia dengan produksi mencapai 2,284 juta ton [5] namun limbah tersebut sebagian besar hanya dimanfaatkan untuk aplikasi dengan nilai ekonomi yang relatif rendah seperti cotton bud, isian boneka dan bantal atau dimusnahkan.

Disamping itu faktor lain yang mendorong penggunaan kapas limbah tekstil ini adalah karena sejauh ini belum diteliti atau dimanfaatkan sebagai bahan baku selulosa alternatif serta ketiadaan suatu kelas dari serat kapas di Indonesia yang umum digunakan sebagai sumber selulosa baik dalam penelitian maupun Industri, yakni linter kapas[6]. Linter kapas tersebut merupakan kelas serat kapas yang menempel di permukaan biji kapas, dimana bagian tersebut memiliki berat molekul yang rendah dengan kandungan selulosa yang dapat mencapai $99 \%$ [6], sehingga dapat digunakan langsung dalam pembuatan selulosa teregenerasi, umumnya linter tersebut dipisahkan dengan bagian serat kapas yang lebih panjang (disebut sebagai lint) yang pada dasarnya merupakan bagian kapas yang digunakan dalam pembuatan produk tekstil, termasuk pada kapas limbah yang diperoleh.

Hidrolisis asam sulfat merupakan salah satu proses yang umum dilakukan dalam tahapan pengolahan suatu bahan lignoselulosa, yang dimana proses hidrolisis asam dapat melarutkan penyusun dinding sel tumbuhan seperti lignin dan hemiselulosa sehingga selulosa yang diselubunginya dapat terbebas [7], selain itu hidrolisis asam juga dapat memperpendek rantai selulosa yang bertujuan agar lebih mudah dilarutkan. Karakteristik selulosa teregenerasi yang memiliki struktur kimia serupa dengan selulosa asli berpotensi menyebabkan bioplastik yang dihasilkan akan memiliki sifat dan karakteristik yang serupa dengan selulosa native, diantaranya akan berpengaruh pada sifat mekanik sangat dipengaruhi oleh interaksi yang terjadi antar rantai yang menyusunnya.

Sifat mekanik yang terbentuk juga dapat dipengaruhi oleh berat molekul selulosa yang digunakan, dimana dapat bervariasi sebagai akibat dari proses ekstraksi dengan asam yang dilakukan. Pengaruh konsentrasi asam sulfat yang digunakan terhadap terhadap berat molekul selulosa yang terekstraksi dan sifat mekanik dari bioplastik yang dibuat dari selulosa yang berasal dari kapas limbah tersebut akan dikaji dalam penelitian ini. Selulosa yang diekstraksi dari kapas limbah dalam penelitian ini dibuat menjadi bioplastik selulosa teregenerasi dalam bentuk bulk, atau plastik dengan ketebalan lebih dari 0,4 $\mathrm{mm}$ (ASTM D638).

Bioplastik selulosa teregenerasi dalam bentuk bulk pada perkembangannya saat ini masih jarang dikaji dan sebagian besar lebih terfokus pada pengembangan dalam bentuk film yang berorientasi pada aplikasi kemasan $[8,9]$. Melalui penelitian ini diharapkan dapat diperoleh gambaran mengenai sifat fisik dari bioplastik selulosa teregenerasi dalam bentuk bulk yang dihasilkan dari selulosa dari kapas limbah industri tekstil. 


\section{METODE PERCOBAAN}

\section{Bahan dan Alat}

Kapas limbah industri pembuatan benang katun yang digunakan diperoleh dari UD Mulya Jaya, Desa Cigentur, Majalaya, Kabupaten Bandung. Asam sulfat yang digunakan berasal dari Pudak, Bandung; $\mathrm{NaOH}$ dari Brataco Chemica Bandung; Urea dari Central Kimia, Bandung; dan Aseton dari Justus Kimiaraya, Bandung. Air deionisasi diperoleh dari Program Studi Kimia, Fakultas Matematika dan Ilmu Pengetahuan Alam, ITB.

Viskometer ubbelohde CANNON IC D834 digunakan untuk mengukur berat molekul rerata viskositas $\left(M W_{\eta}\right)$. Pengujian tarik dilakukan menggunakan alat Tensilon RTF-1310 di laboratorium Teknik Produksi, Program Studi Teknik Mesin, Fakultas Teknik Mesin dan Dirgantara, Institut Teknologi Bandung. Pengujian FT-IR dilakukan dengan alat Shimadzu Prestige 21 di program studi Kimia, Fakultas Matematika dan Ilmu Pengetahuan Alam (FMIPA), Institut Teknologi Bandung. Pengukuran densitas dilakukan dengan Timbangan Digital KERNABJ 220-4NM

\section{Cara Kerja}

Kapas limbah dipotong sepanjang kurang lebih $1 \mathrm{~cm}$ sebelum digunakan. Kandungan lignoselulosa dari kapas limbah diuji dengan menggunakan Metode Chesson [10] Hidrolisis dengan menggunakan asam sulfat dilakukan untuk mengekstraksi selulosa dari kapas limbah. Hidrolisis terhadap kapas dilakukan pada suhu $100{ }^{\circ} \mathrm{C}$ selama $2 \mathrm{jam}$. Konsentrasi asam sulfat divariasikan pada $0,5 \mathrm{M}$; $1 \mathrm{M}$; 1,5 M, dan $2 \mathrm{M}$. Hasil hidrolisis kemudian disaring dengan kertas saring dan dikeringkan pada suhu ruang. Larutan selulosa diperoleh melalui metode freeze - thawing dengan medispersikan selulosa yang diperoleh dari hasil hidrolisis didalam larutan $7 \%$ $\mathrm{NaOH} / 12 \%$ Urea dan dibekukan pada suhu $10{ }^{\circ} \mathrm{C}$ selama 24 jam. Larutan selulosa yang diperoleh kemudian disaring dan dibentuk menjadi plastik melalui metode solution casting dengan koagulan aseton dan air pada perbandingan $2: 1$. Hidrogel selulosa yang diperoleh kemudian dikeringkan pada suhu ruang.

Karakterisasi berat molekul dari selulosa yang diperoleh melalui proses hidrolisis terhadap kapas limbah dilakukan melalui metode berat molekul rerata viskositas. Viskometer ubbelohde digunakan untuk mengukur viskositas intrinsik dari [ $\eta$ ] dari larutan selulosa yang kemudian dikonversi menjadi berat molekul rerata viskositas $\left(M W_{\eta}\right)$ menggunakan Persamaan (1) [11-13].

$$
[\eta]=2,45 \times 10^{-2} M W_{\eta}^{0,815}
$$

Pengujian tarik dilakukan dengan standar ASTM D638 dengan kecepatan penarikan $1 \mathrm{~mm} /$ menit. Pengujian densitas dilakukan dengan standar ASTM D792.

\section{HASIL DAN PEMBAHASAN}

Pengujian kandungan lignoselulosa dari kapas limbah yang diperoleh dilakukan secara kuantitatif dengan metode Chesson. Hasil yang diperoleh menunjukkan bahwa kapas limbah yang digunakan memiliki persentase kandungan lignoselulosa yang umum dimiliki oleh kapas, yakni dengan persentase at terlarut dalam air, hemiselulosa, selulosa dan lignin masing-masing berkisar antara $1 \%$ hingga $7 \% ; 2 \%$ hingga $6,4 \% ; 82 \%$ hingga $96 \%$; dan $0 \%$ hingga $5 \%$ [14]. Prosentase kandungan selulosa dari kapas limbah yang besar, yakni mencapai 82,43\% menunjukkan bahwa kapas limbah tersebut berpotensi untuk dimanfaatkan sebagai sumber alternatif selulosa disamping linter kapas.

Pengukuran berat molekul rerata viskositas dilakukan untuk melihat seberapa besar pengaruh yang ditimbulkan dari konsentrasi asam yang digunakan terhadap perubahan berat molekul selulosa yang diperoleh. Hasil pengujian yang diperoleh ditunjukkan pada Gambar 1. Data hasil pengujian berat molekul menunjukkan bahwa jika dibandingkan dengan berat molekul dari selulosa kapas native $(0 \mathrm{M})$, selulosa hasil ekstraksi memiliki nilai yang jauh dibawah selulosa kapas native [15]. Data hasil pengujian yang diperoleh juga menunjukkan berat molekul selulosa cenderung menurun seiring dengan peningkatan konsentrasi asam yang digunakan, yakni berkisar antara $2,73 \times 10^{4} \mathrm{~g} / \mathrm{mol}$ pada konsentrasi asam sulfat $0,5 \mathrm{M}$ hingga $1,94 \times 10^{4} \mathrm{~g} / \mathrm{mol}$ pada konsentrasi $2 \mathrm{M}$. Penurunan berat molekul yang terjadi tersebut disebabkan oleh peningkatan jumlah ion hidrogen dalam larutan yang digunakan, dimana akan

Table 1. Persentase kandungan lignoselulosa kapas limbah yang diperoleh.

\begin{tabular}{cc}
\hline Kandungan & Persentase $(\%)$ \\
\hline Zat terlarut dalam air & 7,25 \\
(mendidih) & \\
Hemiselulosa & 6,46 \\
Selulosa & 82,43 \\
Lignin & 3,84 \\
\hline
\end{tabular}

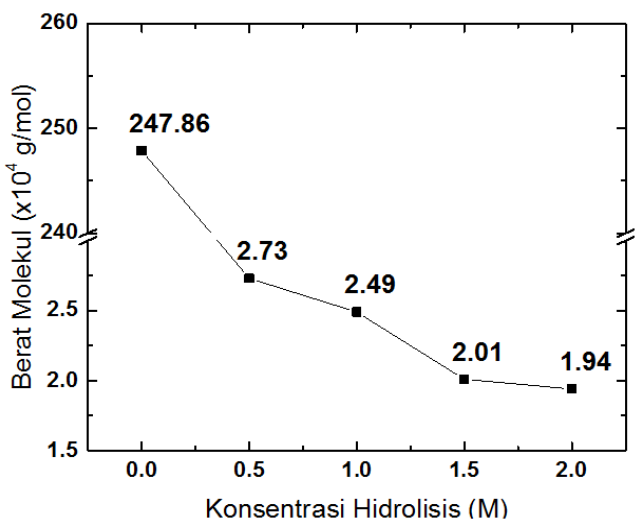

Gambar 1. Berat molekul rerata viskositas hasil hidrolisis kapas limbah pada berbagai konsentrasi asam, kondisi native (0 M) didasarkan pada literatur [15] 
turut meningkat seiring dengan meningkatnya konsentrasi asam yang digunakan. Ion hidrogen berperan sebagai katalis dalam suatu proses hidrolisis ikatan glikosidik rantai selulosa [16], dimana dengan semakin banyaknya ion hidrogen yang hadir maka akan semakin besar potensi reaksi hidrolisis terhadap ikatan glikosidik yang terjadi sehingga akan menghasilkan selulosa dengan berat molekul yang lebih kecil.

Selulosa yang diperoleh dari kapas limbah industri tekstil telah diolah menjadi bioplastik selulosa teregenerasi dengan ketebalan rata-rata $0,87 \mathrm{~mm}$. Karakterisasi dilakukan untuk mengetahui sifat mekanik dari bioplastik selulosa teregenerasi yang dihasilkan khususnya terkait pengaruh dari berat molekul dari selulosa sebagai efek dari konsentrasi asam yang digunakan.

Sifat mekanik plastik selulosa teregenerasi dari selulosa kapas limbah tekstil diuji dengan pengujian tarik. Hasil yang diperoleh menunjukkan bahwa plastik selulosa teregenerasi yang dihasilkan secara umum memiliki nilai sifat mekanik yang cukup bervariasi dengan kecenderungan menurun pada berat molekul $2,73 \times 10^{4} \mathrm{~g} / \mathrm{mol}$ hingga $2,01 \times 10^{4} \mathrm{~g} / \mathrm{mol}$ dengan nilai modulus, persen elongasi, dan kekuatan tarik masingmasing berkisar antara $11,39 \mathrm{GPa}$ hingga $8,99 \mathrm{GPa}$; $0,92 \%$ hingga $0,52 \%$; dan 49,24 MPa hingga 31,54 MPa namun kembali meningkat pada $1,93 \times 10^{4} \mathrm{~g} / \mathrm{mol}$ dengan nilai modulus, persen elongasi, dan kekuatan tarik masing-masing berkisar 11,28 GPa; 0,78\% dan 49,99 MPa, seperti yang ditunjukkan pada Gambar 2. Peningkatan sifat mekanik yang terjadi kemungkinan

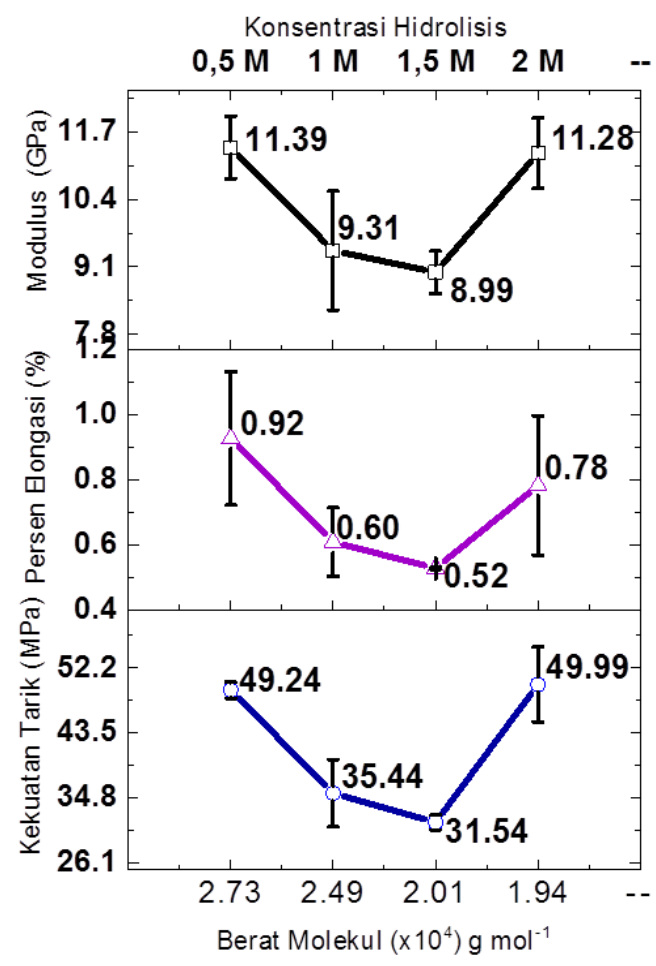

Gambar 2. Sifat mekanik plastik selulosa teregenerasi pada berbagai berat molekul. disebabkan oleh adanya faktor lain seperti porositas dimana pada plastik yang dibuat dari selulosa dengan berat molekul 1,93 x $10^{4} \mathrm{~g} / \mathrm{mol}$ terdapat dalam jumlah yang lebih sedikit.

Kecenderungan yang serupa juga ditunjukkan pada hasil pengujian densitas, seperti yang ditunjukkan pada Gambar 3, dimana densitas cenderung menurun pada berat molekul $2,73 \times 10^{4} \mathrm{~g} / \mathrm{mol}$ sampai dengan $2,01 \times 10^{4} \mathrm{~g} / \mathrm{mol}$ dan kembali meningkat pada $1,93 \times 10^{4} \mathrm{~g} / \mathrm{mol}$. Salah satu faktor yang dapat mempengaruhi perubahan densitas tersebut adalah keberadaan dari ruang-ruang kosong (porositas) yang terbentuk didalam plastik yang dihasilkan. Faktor penyebab yang berkontribusi terhadap munculnya porositas dalam penelitian ini diperkirakan adalah selulosa tersulfatisasi [17]. Selulosa tersulfatisasi adalah selulosa yang sejumlah gugus hidroksilnya $(-\mathrm{OH})$ tersubstisusi oleh gugus sulfat $\left(\mathrm{OSO}^{3-}\right)$ [18-21].

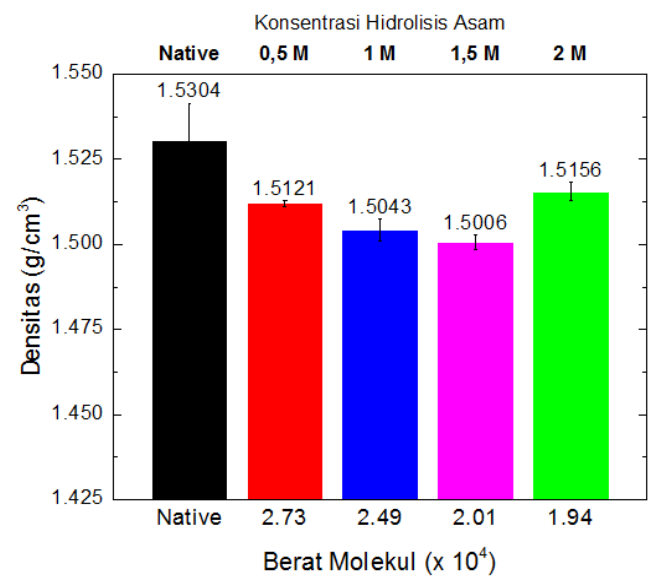

Gambar 3. Densitas plastik selulosa tergenerasi pada berbagai berat molekul.

Pada Gambar 4.(a) menunjukan spektrum FT-IR kapas limbah dan hasil ekstraksi pada berbagai konsentrasi asam. Gambar 4(b) memperlihatkan segmen spektrum wilayah fingerprint pada bilangan gelombang $1800 \mathrm{~cm}^{-1}$ hingga $400 \mathrm{~cm}^{-1}$, Gambar 4 (b) Segmen spektrum $F T-I R$ pada bilangan gelombang $1050 \mathrm{~cm}^{-1}$ hingga $1000 \mathrm{~cm}^{-1}$, Gambar 4 (d) Kecenderungan nilai absorbansi pada masing masing hasil hidrolisis pada bilangan gelombang $1033 \mathrm{~cm}^{-1}$

Spektrum pengujian hasil FT-IR ditunjukkan pada Gambar 4(a) dan Gambar 4 (b). Puncak absorbansi yang muncul pada $1430 \mathrm{~cm}^{-1}$ dan $898 \mathrm{~cm}^{-1}$ masing-masing merujuk pada getaran bending simetris $\mathrm{CH}_{2}$ dan stretching $\mathrm{C}-\mathrm{O}-\mathrm{C}$ ikatan glikosidik betha1-4 dari selulosa [22]. Pada spektrum native tampak ada puncak absorbansi yang muncul pada1519 $\mathrm{cm}^{-1}$ dan $1711 \mathrm{~cm}^{-}$ ${ }^{1}$ yang masing-masing merujuk kepada keberadaan lignin dan hemiselulosa [23, 24]. Puncak absorbansi $1519 \mathrm{~cm}^{-1}$ dan $1711 \mathrm{~cm}^{-1}$ tersebut tidak muncul pada spektrum hasil hidrolisis yang mengindikasikan bahwa lignin dan hemiselulosa telah dapat dihilangkan melalui proses 

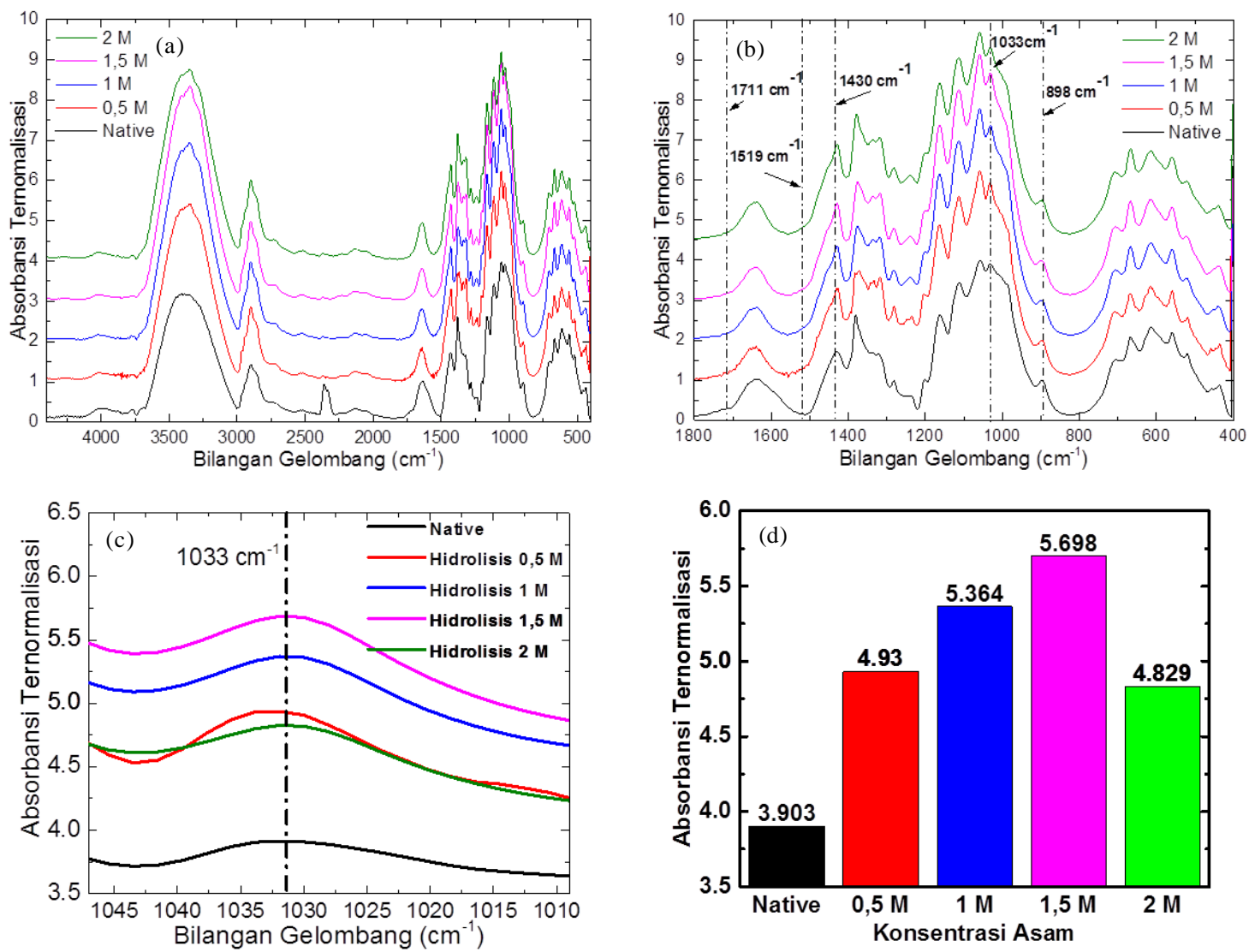

Gambar 4. (a). Spektrum FT-IR kapas limbah dan hasil ekstraksi pada berbagai konsentrasi asam, (b). Segmen spektrum wilayah fingerprint pada bilangan gelombang $1800 \mathrm{~cm}^{-1}$ hingga $400 \mathrm{~cm}^{-1}$, (c). Segmen spektrum FT-IR pada bilangan gelombang $1050 \mathrm{~cm}^{-1}$ hingga $1000 \mathrm{~cm}^{-1}$ dan (d). Kecenderungan nilai absorbansi pada masing masing hasil hidrolisis pada bilangan gelombang $1033 \mathrm{~cm}^{-1}$.

hidrolisis.Modifikasi terhadap gugus hidroksil pada selulosa dapat dilihat melalui perubahan yang terjadi pada puncak absorbasi $1033 \mathrm{~cm}^{-1}$ yang merujuk pada C-O stretching pada selulosa [25] atau secara lebih spesifik merujuk pada ikatan antara karbon dengan gugus hidroksil pada rantai selulosa tersebut.

Peningkatan absorbansi yang terjadi pada gugus hidroksil tersebut dapat mengindikasikan adanya perubahan terhadap gugus hidroksil dari selulosa seperti mengalami substitusi atau grafting [26], khususnya jika tersubstitusi dengan atom atau molekul yang lebih besar dari gugus hidroksil. Spektrum yang diperoleh menunjukkan bahwa setelah proses hidrolisis tampak terjadi peningkatan absorbansi pada puncak absorbansi tersebut jika dibandingkan dengan pada kondisi native yang mengindikasikan terjadi substitusi pada gugus hidroksilnya. Indikasi substitusi terhadap gugus hidroksil tersebut kemungkinan dapat dikaitkan dengan keberadaan selulosa tersulfatisasi yang pada spektrum juga ditunjukkan pada bilangan gelombang $1033 \mathrm{~cm}^{-1}$ yang merujuk pada getaran stretching grup sulfat [20].

Hasil yang diperoleh menunjukkan adanya kecenderungan peningkatan absorbansi pada berat molekul 2,73 x $10^{4} \mathrm{~g} / \mathrm{mol}$ hingga $2,01 \times 10^{4} \mathrm{~g} / \mathrm{mol}$ dan kembali menurun pada $1,93 \times 10^{4} \mathrm{~g} / \mathrm{mol}$, seperti yang ditunjukkan pada Gambar 4(c) dan Gambar 4(d) yang mengindikasikan variasi jumlah grup sulfat yang terkandung pada masing-masing selulosa tersebut. Perbedaan yang terjadi tersebut kemungkinan disebabkan pada hasil hidrolisis $2 \mathrm{M}$, partikel selulosa yang terekstraksi telah banyak kehilangan bagian amorfnya dan menyisakan lebih banyak bagian kristalin. Bagian kristalin yang rapat menyulitkan molekul sulfat untuk menembus dan mensubstitusi gugus hidroksil yang berada pada rantai selulosa di dalam wilayah kristalin, sehingga hanya mempengaruhi gugus hidroksil pada rantai selulosa yang berada di permukaan [20].

Fenomena terbentuknya selulosa tersulfatisasi dalam bioplastik selulosa teregenerasi yang diperoleh ini disebabkan sebagai efek samping penggunaan asam sulfat dalam proses ekstraksi selulosa dari kapas melalui proses hidrolisis tersebut [17,20,27]. Gugus selulosa tersulfatisasi tersebut memiliki muatan negatif [28], yang dimana hal ini dapat menyebabkan adanya gaya tolak ketika gugus tersebut bertemu dengan gugus sulfat lain pada rantai selulosa yang berdampingan saat regenerasi berlangsung, sehingga menyebabkan tidak terbentuknya ikatan sekunder antar keduanya pada bagian tersebut dan menjadi suatu porositas [17], seperti yang diilustrasikan pada Gambar 5. Semakin besar keberadaan 


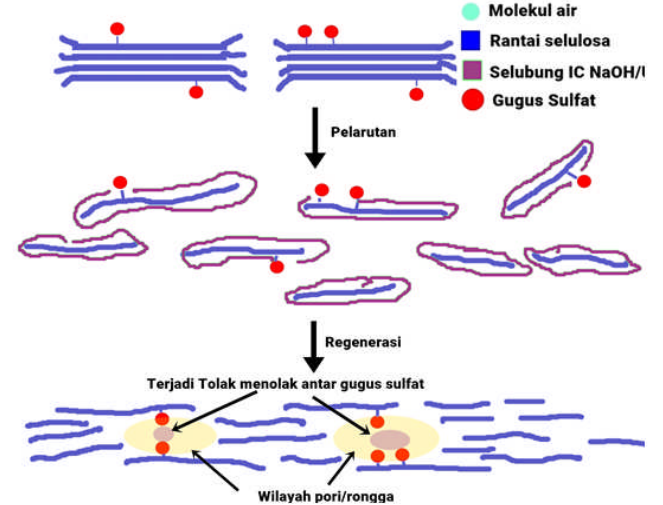

Gambar 5. Ilustrasi prediksi fenomena terbentuknya rongga sebagai akibat dari keberadaan gugus sulfat setelah regenerasi.

selulosa tersulfatisasi dalam selulosa yang digunakan akan makin besar pula kemungkinan jumlah porositas yang terbentuk dan sebaliknya. Hal ini pada dasarnya dapat dikaitkan dengan fenomena yang terjadi pada densitas maupun sifat mekanik yang memiliki pola serupa. Keberadaan dari pori tersebut dapat menyebabkan penurunan densitas karena semakin banyak ruang kosong didalamnya yang secara lebih lanjut berpengaruh terhadap sifat mekanik sebagai akibat terjadinya konsentrasi tegangan pada porositas tersebut ketika diberikan pembebanan, dimana semakin banyak porositas, maka akan semakin lebih cepat material tersebut untuk mengalami kegagalan dibawah kondisi yang seharusnya [29].

Secara garis besar, dalam kaitannya terhadap sifat mekanik, hasil pengujian yang diperoleh menunjukkan bahwa variasi konsentrasi asam yang digunakan dalam penelitian ini menyebabkan adanya variasi jumlah selulosa tersulfatisasi yang terbentuk yang menyebabkanpembentukan porositas yang mempengaruhi sifat mekanik dari plastik yang dihasilkan tersebut. Namun, dari segi nilai sifat mekanik yang diperoleh, khususnya dari kekuatan tarik, seperti yang

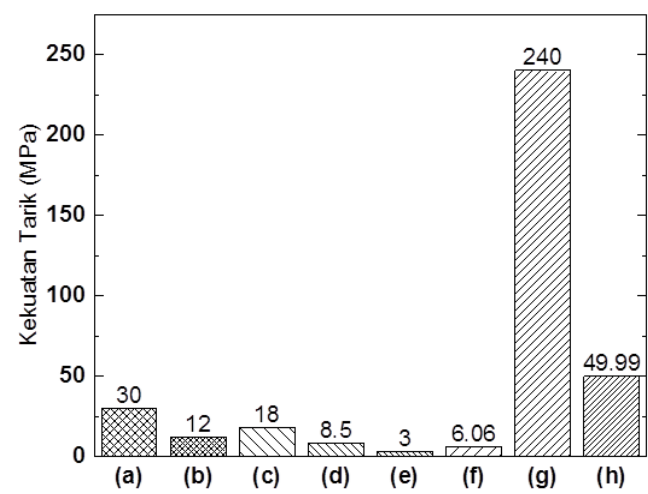

Gambar 6. Sebaran kekuatan tarik beberapa jenis plastik dibandingkan dengan hasil penelitian, (a). Komersil : PP [30], (b). Komersil : LDPE [30], (c). Bioplastik : Thermoplastic starch (TPS) Jagung [30], (d). Bioplastik : SPI/Maleic Anhydride [31], (e). Bioplastik : Soy Protein Isolate/Gliserol/Sorbitol[31], (f). Bioplastik : TPS Singkong/Gliserol [32], (g). Bioplastik : Plastik Selulosa Teregenerasi dari linter kapas (bulk)-Hot Pressing; [8] dan (h). bioplastik. ditunjukkan pada Gambar 6, plastik selulosa teregenerasi dalam penelitian ini memiliki nilai yang lebih tinggi dibanding beberapa jenis plastik komersil dari minyak bumi seperti polypropylene $(P P)$ dan Low Density Polyethylene (LDPE) dan bioplastik berbahan hayati seperti pati dan protein, namun masih lebih rendah dibanding plastik selulosa teregenerasi dalam bentuk bulk yang dibuat dari linter kapas, hal ini kemungkinan dikarenakan adanya perbedaan berat molekul selulosa (karena menggunakan kapas linter langsung tanpa hidrolisis) dan metode pemrosesan yang digunakan [8].

\section{KESIMPULAN}

Hasil yang diperoleh menunjukkan bahwa peningkatan konsentrasi asam yang digunakan dalam proses hidrolisis mengakibatkan penurunan berat molekul selulosa yang terekstraksi. Penurunan berat molekul selulosa ini berpengaruh terhadap sifat mekanik dari plastik selulosa teregenerasi yang dihasilkan. Namun demikian, berat molekul selulosa yang hasil ekstraksi tidak berbanding lurus dengan sifat mekanik plastik selulosa teregenerasi. Faktor lain yang mempengaruhi sifat mekanik plastik selulosa teregenerasi adalah terbentuknya porositas sebagai akibat dari substitusi gugus hidroksil selulosa menjadi selulosa tersulfatisasi. Sifat optimum selulosa teregenerasi yang dihasilkan, dengan mempertimbangkan sifat mekanik yang dihasilkan secara umum diperoleh dari selulosa hasil hidrolisis asam sulfat $0,5 \mathrm{M}$, yang memilikipersen elongasi dan modulus tertinggi dalam penelitian ini. Penelitian lebih lanjut perlu dilakukan kembali khususnya untuk mengkonfirmasi keberadaan void beserta dimensinya serta upaya untuk menghindari terbentuknya selulosa tersulfatisasi atau penanggulangannya.

\section{UCAPAN TERIMAKASIH}

Penulis mengucapkan terima kasih PT Mulya Jaya atas bantuan bahan baku kapas limbah yang diberikan kepada penulis, laboratorium Teknik produksi, ibu Eryanti Kalembang M.T. dari PTM BPPT Serpong atas bantuannya dalam pengujian sampel, dan saudara Asril Senoaji,M.T. dari Sekolah Tinggi Teknologi Tekstil atas bantuan dan saran yang diberikan kepada penulis

\section{DAFTAR ACUAN}

[1]. S. Pilla. Handbook of Bioplastic and Biocomposites Engineering Application. Salem : Scrievener Publishing, pp. 349, 2011.

[2]. R. D. Harbison, M. M. Bourgeois, dan G. T. Johnson. Hamilton and Hardy's Industrial Toxicology, Sixth Edition. Hoboken :John Wiley \& Sons, Inc., pp. 792, 2015.

[3]. M. Pandey, M. M. Abeer, M. C. Iqbal, and M. Amin. "Dissolution Study of Bacterial Cellulose (Nata De 
Pengaruh Variasi Konsentrasi Hidrolisis Asam Sulfat Terhadap Sifat Mekanik Plastik Selulosa Teregenerasi dari Kapas Limbah Tekstil dengan Pelarut NaOH/Urea (Raden Reza Rizkiansyah)

Coco) From Local Food Industry: Solubility Behavior \& Structural Changes." Int J Pharm Pharm Sci, vol 6, pp. 89-93, 2015.

[4]. X. Zhang. Fundamentals of Fiber Science. Pennysylvania: DeStech Publishing Inc., pp. 55, 2014.

[5]. N. Febrina. "Analisis Strategi PT Apac Inti Corpora Diindustri TPT.” Tugas Akhir Sarjana, Universitas Gajah Mada, Indonesia, 2013.

[6]. M. K. Ryszard. Handbook of natural fibres Volume 1: Types, properties and factors affecting breeding and cultivation. Cambridge: Woodhead Publishing Limited, pp. 67, 2012.

[7]. N. Bujang, M.N.M. Rodhi, M.Musa, F. Subari, N. Idrisa, N.Shuhada M.Makhtar, K.H.K. Hamid. "Effect of Dilute Sulfuric Acid Hydrolysis of Coconut Dregs on Chemical and Thermal Properties." Procedia Engineering, vol. 68, pp. 372-378, 2013.

[8]. Q. Wang, J.Cai, L.Zhang, M. Xu, H. Cheng, C. C. Han, S. Kuga, J. Xiao, and R. Xiao. "A Bioplastic with High Strength Constructed from a Cellulose Hydrogel by Changing The Aggregated Structure." J. Mater. Chem. A, vol 1, pp. 6678-6686, 2013.

[9]. S.Wang, A. Lu, and L. Zhang. "Recent Advances in Regenerated Cellulose Materials." Progress in Polymer Science, vol .53, pp. 169-206, 2015.

[10]. Mahyati, A.R Patong, M.N Djide, P. Taba, "Biodegradation of Lignin From Corn Cob By Using A Mixture Of Phanerochaete Chrysosporium, Lentinus Edodes And Pleurotus Ostreatus." International Journal of Scientific \& Technology Research, vol . 2, no. 11, pp.79-82, 2013.

[11]. J. Zhou, L. Zhang and J. Cai. "Behavior of Cellulose in $\mathrm{NaOH} / \mathrm{Urea}$ Aqueous Solution Characterized by Light Scattering and Viscometry." Journal of Polymer Science: Part B: Polymer Physics, vol. 42, pp. 347-353, Jul. 2003.

[12]. D.N.S. Hon dan N. Shiraishi.Wood and Cellulosic Chemistry, Second Edition, Revised, and Expanded. New York :Marcell Dekker, pp. 290, 2001.

[13]. S. Zhang, W. C.Wang, F. X. Li and J. Y. Yu."Swelling and Dissolution of Cellulose in $\mathrm{NaOh}$ Aqueous Solvent Systems." Cellulose Chem. Technol., vol. 47, pp. 671-679, Oct. 2012.

[14]. S.J. Eichhorn, J.W.S. Hearle, Jaffe M, T. Kikutani. Handbook of Textile Fibre Structure Volume 2: Natural, Regenerated, Inorganic and Specialist Fibres. Boca Raton: CRC Press, pp. 64, 2009.

[15]. D. Fengel, G. Wegener. Wood: chemistry, ultrastructure, reactions. New York : De Gruyter, pp. 74, 1989.

[16]. L. Kupiainen. "Dilute Acid Catalysed Hydrolysis of Cellulose-Extension to Formic Acid." Disertasi Doktor, University of Oulu, Amerika Serikat, 2012.

[17]. P. Lu and Y. L. Hsieh.. "Preparation and Properties of Cellulose Nanocrystals: Rods, Spheres, and
Network." Carbohydrate Polymers, vol. 82, pp. 329-336, 2010.

[18]. L. Du, J. Wang, Y. Zhang, C. Qi, M. P. Wolcott and Z. Yu. "Preparation and Characterization of Cellulose Nanocrystals from the Bio-ethanol Residuals." Nanomaterials, vol. 7, pp. 51, 2017.

[19]. L. C.Yeng, M. U. Wahit, and N. Othma. "Thermal And Flexural Properties Of Regenerated Cellulose(RC)/Poly(3-Hydroxybutyrate)(PHB) Biocomposites." Jurnal Teknologi (Sciences \& Engineering), vol.75, pp. 107-112, 2015.

[20]. N. Lin and A. Dufresne. "Surface Chemistry, Morphological Analysis and Properties of Cellulose Nanocrystals with Gradiented Sulfation Degrees." Nanoscale, vol. 6, pp. 5384-5393, 2014.

[21]. M. A. Martins, E. M. Teixeira, A. C. Correa, M. Ferreira, and L. H. C. Mattoso. "Extraction and Characterization of Cellulose Whiskers from Commercial Cotton Fibers.”vol 46, pp. 7858-7864, Dec.2011.

[22]. D. Ciolacu, F. Ciolacu and V.I. Popa, "Amorphous Cellulose - Structure AndCharacterization" Cellulose Chem. Technol., vol. 45, pp. 13-21, 2011.

[23]. Silvio Vaz Jr.,Analytical Techniques and Methods for Biomass. Cham : Springer International Publishing, pp. 67, 2016.

[24]. Z. Fang. Pretreatment Techniques for Biofuels and Biorefineries. Berlin : Springer-Verlag, pp. 450, 2013.

[25]. M. Ueland, J.M. Howes, S.L. Forbes. and B.H. Stuart. "Degradation patterns of Natural and Synthetic Textiles on a Soil Surface During Summer and Winter Seasons Studied Using ATR-FTIR Spectroscopy", Spectrochimica Acta Part A: Molecular and Biomolecular Spectroscopy, vol. 185, pp. 69-76, 2017.

[26]. Y. Gao, Q. Li, Y. Shi, and R. Cha. "Preparation and Application of Cationic Modified Cellulose Fibrils as a Papermaking Additive." International Journal of Polymer Science, pp. 1-8, 2016.

[27]. R. R. Rizkiansyah. "Ekstraksi Mikrokristalin Selulosa dari Bambu Apus (Gigantochloa apus) dan Pemanfaatannya Sebagai Penguat pada Biokomposit Pati Tapioka/MCC." Tugas Akhir Sarjana, Insitut Teknologi dan Sains Bandung, Indonesia, 2014.

[28]. L. Zhong, S. Fu, X. Peng, H. Zhan, dan R. Sun. "Colloidal Stability of Negatively Charged Cellulose Nanocrystalline in Aqueous Systems." Carbohydrate Polymers, vol 90, pp. 644-649, 2012.

[29]. P. J. Shull. Nondestructive Evaluation: Theory, Techniques, and Applications. New York, CRC Press, pp. 690, 2002.

[30]. Z. A. Tariq. "Physical and Chemical Investigations of Starch Based Bio-Plastics."Disertasi Doktoral, University of Leicester, KerajaanBritania Raya, 2015. 
[31]. D. Grewell, S.T. Carolan, and G. Srinivasan. "Development of Soy Protein Plastics Using Functional Chemistry for Short-Life Biodegradable Applications." J. Renew. Mater., vol. 1, pp. 231-241, 2013.

[32]. M. Felix, V. Carpintero, A. Romero and A. Guerrero. "Influence of Sorbitol on Mechanical and PhysicoChemical Properties of Soy Protein-Based Bioplastics Processed by Injection Molding". Polímeros, vol.26, no. 4, pp. 277-281, 2016.
[33]. A.C. Souza, R. Benze, E.S. Ferrão, C. Ditchfield, A.C.V. Coelho, dan C.C. Tadini. "Cassava Starch Biodegradable Films: Influence of Glycerol and Clay Nanoparticles Content on Tensile and Barrier Properties and Glass Transition Temperature." LWT - Food Science and Technology, vol. 46, pp. 110-117, 2012. 